\title{
Peningkatan Ekonomi Peternak Sapi Perah dan Masyarakat Desa Melalui Diversifikasi Produk Olahan Dengan Bahan Baku Susu Sapi
}

\author{
Aristha Purwanthari Sawitri ${ }^{1}$, Purity Sabila Ajiningrum ${ }^{2}$, Martha Suhardiyah ${ }^{3}$ \\ Universitas PGRI Adi Buana Surabaya ${ }^{1,2,3}$, \\ aristha_p@yahoo.co.id ${ }^{1}$, puritysabila@gmail.com ${ }^{2}$, martha_suhardiyah@yahoo.com ${ }^{3}$
}

\begin{abstract}
People in the village of Seketi sub-district of Sidoarjo Regency Balongbendo his livelihood is as a breeder cow's milk. From the survey results and discussions with dairy farmers can note that the selling price for dairy cows is still very low, with the sale price low enough, surely cow's milk dairy farmers suffered losses. Based on problems experienced by cattle farmers, encouraging the team to perform the community service in the village of Seketi by providing training to cattle farmers and villagers about the processing of a product that is made from cow's milk that is yoghurt, training, recording of accounting and marketing products after the training. With the given training is expected to increase the economic value of cattle farmers and villagers.
\end{abstract}

Keywords: Cow's milk; Diversification; Yogurt; Milk Crackers

\begin{abstract}
Abstrak
Masyarakat di Desa Seketi Kecamatan Balongbendo Kabupaten Sidoarjo mata pencaharian nya adalah sebagai peternak susu sapi. Dari hasil survey dan pembicaraan dengan peternak sapi perah dapat diketahui bahwa harga jual untuk hasil peternakan susu sapi masih sangat rendah, dengan harga jual yang cukup rendah, tentunya peternak susu sapi mengalami kerugian. Berdasarkan permasalahan yang dialami oleh peternak sapi, mendorong tim untuk melakukan kegiatan pengabdian di Desa Seketi dengan memberikan pelatihan mengenai pengolahan produk yang berbahan susu sapi yaitu yoghurt, pelatihan pelaporan akuntansi dan pemasaran produk. Dengan diberikan pelatihan ini diharapkan dapat meningkatkan nilai ekonomi peternak sapi dan masyarakat desa.
\end{abstract}

Kata Kunci: Susu Sapi; Diversifikasi; Yoghurt; Kerupuk Susu 


\section{A. PENDAHULUAN}

\section{Desa Seketi Kecamatan Balong-} bendo Kabupaten Sidoarjo terdapat 3 peternak sapi dengan jumlah sebanyak 18 ekor. Dari hasil survey dan pembicaraan dengan peternak sapi perah dapat diketahui bahwa hasil susu yang dihasilkan peternak sapi perah di desa Seketi nantinya akan dijual kembali kepada pengusaha susu sapi dengan harga yang cukup rendah yaitu Rp. 5.000/liter, sedangkan pengusaha susu sapi dapat menjual kembali hasil susu sapi ke konsumen sebesar Rp. 10.000/liter. Dengan harga jual yang cukup rendah, tentunya peternak susu sapi mengalami kerugian. Susu sapi merupakan produk yang mudah sekali mengalami kerusakan. Karena memiliki sifat yang mudah rusak, maka pengolahan susu harus diperhatikan dengan baik agar susu tetap terjaga kualitas gizinya. Penurunan kadar $\mathrm{pH}$ yang terdapat dalam susu menyebabkan ketidak stabilan dari kasein dan terkoagulasi menjadi yoghurt. Kualitas yoghurt sangat dipengaruhi oleh jenis susu, starter dan suplemen yang digunakan dalam pembuatan yoghurt (Abraham et al., 1993). Menurut Abubakar et al. (2000), jenis susu yang baik untuk pembuatan yoghurt berdasarkan kualitasnya dan preferensi konsumen, berturut-turut adalah susu sapi, susu kambing, susu kental manis, susu krim dan susu skim. Sedangkan suhu penyimpanan yoghurt yang dianjurkan adalah $5^{0} \mathrm{C}$.

Salah satu kelemahan dari susu sapi yaitu susu sapi merupakan produk yang mudah sekali rusak dan ini merupakan permasalahan bagi peternak sapi. Karena sifat susu yang mudah rusak, maka kami melakukan memberikan pengetahuan dan keterampilan peternak sapi dalam memanfaatkan produk susu. Peternak sapi perah dapat memanfaatkan hasil susu yang diperoleh dengan mengolahnya menjadi produk yang bernilai ekonomis dan dapat menciptakan lapangan pekerjaan bagi masyarakat sekitar desa Seketi.

Yoghurt merupakan produk susu fermentasi yang dapat diolah menjadi berbagai dengan pilihan rasa yang bervariasi. Pengolahan susu sapi perah menjadi yoghurt merupakan diversifikasi dari produk susu sapi, selain tujuan utamanya yaitu mengawetkan susu agar lebih tahan lama bila disimpan. Produk olahan susu ini dapat memberikan dampak positif pada kesehatan dan secara ekonomis daat meningkatkan nilai jual susu dan dapat meningkatkan pendapatan masyarakat. Inovasi pengolahan susu sapi perah menjadi yoghurt tersebut harus diterapkan ditingkat masyarakat dan peternak sapi perah. Salah satu cara yang dapat dilakukan adalah melalui kemitraan antara akademisi dan peternak. Dalam proses kemitraan ini peternak dan akademisi mempraktekkan teknologi tersebut bersamasama yaitu dalam bentuk pelatihan pembuatan yoghurt, pencatatan akuntansi serta pemasaran online. Dengan adanya sosialisasi manfaat yoghurt dan pelatihan pembuatan yoghurt ini diharapkan dapat meningkatkan pendapatan masyarakat pada umumnya khususnya masyarakat serta peternak sapi perah di Desa Seketi Kecamatan Balongbendo Kabupaten Sidoarjo.

Mengacu pada analisis diatas, beberapa kendala permasalahan yaitu pertama hasil susu sapi yang dijual dengan harga rendah. Kedua, Pemasaran susu yang masih terbatas dan manajemen bisnis yang masih kurang baik. Ketiga Pengetahuan dan ketrampilan tentang perencanaan bisnis, pengelolaan keuangan dan pengemasan produk.

Untuk mengatasi permasalahan mitra, maka pertama tim akan memberikan 
penyuluhan mengenai pentingnya mengkonsumai susu sapi bagi kesehatan. Kedua memberikan pelatihan ketrampilan tentang pemanfaatan produk susu yaitu dengan pembuatan yoghurt untuk dijadikan olahan yang bernilai manfaat dan ekonomi. Kedua memberikan pelatihan mengenai pencatatan keuangan dan menghitung biaya pokok produksi dan harga jual olahan produk susu sapi. Ketiga memberikan pelatihan mengenai pemasaran dengan menggunakan teknologi (pemasaran online).

Target luaran Program Kemitraan Masyarakt ini adalah terciptanya produkproduk olahan susu yaitu yoghurt dan kerupuk susu dengan penerapan teknologi tepat guna.

\section{B. PELAKSAAAN DAN METODE}

Proses Program Kemitraan Masyarakat (PKM) ini dilakukan dengan cara pelatihan, dan pendampingan. Metode ini mencakup secara keseluruhan mulai dari proses hingga hasil yang nyata. Secara keseluruhan metode yang akan dilaksanakan dijelaskan berikut ini:

\section{Penyuluhan Potensi Pengolahan Susu}

Penyuluhan potensi pengolahan susu ini memberikan informasi mengenai manfaat mengkonsumsi susu sapi, produk olahan yang bisa dihasilkan dari susu sapi serta menjelaskan masingmasing produk olahan tersebut. Metode yang digunakan adalah memberikan pemaparan, diskusi, dan tanya jawab

2. Pelatihan Pengolahan Susu

Pelatihan pengolahan produk susu yaitu dengan mendemontrasikan cara pembuatan dari yoghurt dan kerupuk susu. Tim menyediakan bahan dan alat yeng diperlukan selama proses pembuatan produk olahan susu sapi. metode yang digunakan di kegiatan kedua ini adalah diskusi serta tanya jawab, demonstrasi langsung yang dilakukan oleh mitra dan pengarahan yang dilakukan oleh tim terkait dengan pemilihan bahan, proses pembuatan, bahan dan alat yang digunakan.

\section{Pendampingan Manajemen Usaha}

Menjelaskan mengenai Siklus Hidup Perusahaan, peluang bisnis serta resiko bisnis, harga pokok penjualan, dengan cara memperhitungkan biaya produksi secara variabel costing maupun full costing, sistem pencatatan terpisah dan membuat laporan keuangan, strategi pemasaran produk baik secara manual maupun online melalui facebook, WhatApps, Instagram dan google buinesss. Dalam kegiatan ini metode yang digunakan adalah Metode yang digunakan adalah memberikan pemaparan, diskusi, dan tanya jawab

\section{Evaluasi Pelaksanaan}

Tim pengabdian dan mitra melakukan evaluasi dan monitoring kegiatan setelah dilakukannya pelatihan pembuatan produk olahan yang berbahan baku susu sapi, untuk mengetahui permasalahan yang dialami mitra. Dalam kegiatan ini metode yang digunakan adalah diskusi serta tanya jawab terkait dengan permasalahan yang dihadapi mitra terkait dengan manajemen usaha sehingga dari diskusi ini tim melakukan evaluasi dan memberikan solusi permasalahan

\section{C.HASIL DAN PEMBAHASAN}

Hasil dari kegiatan ini adalah terciptanya produk olahan yang berbahan baku susu sapi, adapun produk yang telah dihasilkan dari kegiatan ini adalah yoghurt dan kerupuk susu. Kegiatan ini diawali 
dengan memberikan penyuluhan mengenai manfaat mengkonsumsi susu sapi dan produk olahan dari susu, dengan diberikan penyuluhan mengenai manfaat produk susu sapi, dapat menambah pengetahuan masyarakat desa untuk menilai kualitas dari susu sapi, dimana susu yang baik dapat dilihat dari warna, rasa, bau, berat jenis kekentalan, titik beku, titik didih dan tingkat keasaman. Setelah dilakukan penyuluhan dilanjutkan dengan memberikan pelatihan pengolahan produk dari bahan baku susu.

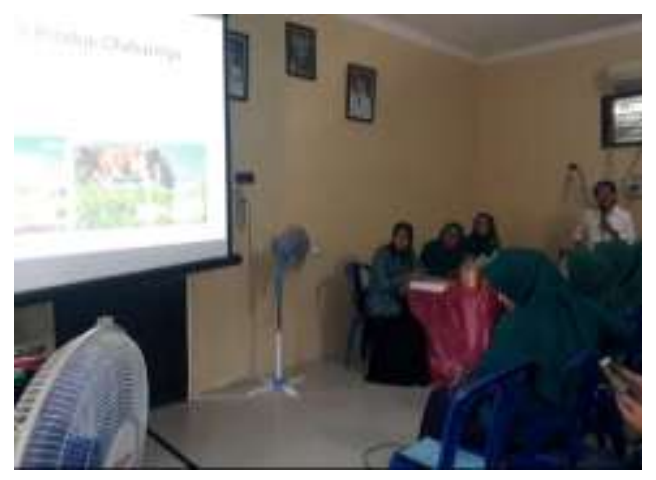

Gambar 1. Penyuluhan manfaat susu dan produk olahan susu sapi

Hasil penyuluhan mengenai manfaat yoghurt yang dilakukan di bulan Juni diketahui bahwa masih kurangnya pengetahuan masyarakat desa dan peternak sapi akan pentingnya yoghurt, hal ini didukung dengan hasil kuesioner dan wawancara yang dilakukan oleh tim. Berdasarkan hasil kuesioner dan wawancara yang dilakukan disimpulkan masyarakat desa tidak pernah mengkonsumsi yoghurt dan hanya mengetahui produk dari media.

Setelah melakukan penyuluhan mengenai potensi pengolahan susu selanjutnya tim memberikan pelatihan pembuatan yoghurt di rumah mitra. Pada tahapan ini mitra mendemontrasikan secara langsung mengenai pengolahan susu sapi menajadi produk yoghurt. Mitra melakukan praktek langsung pembuatan yoghurt mulai dari proses pemanasan susu sapi, pemberian bakteri sampai dengan proses inkubasi, dilakukan sendiri oleh mitra. Tim pengabdian juga memberikan arahan dan masukan dalam proses pembuatan yoghurt, terkait dengan cara pemilihan susu yang baik, cara sterilisasi alat dan bahan yang digunakan, pencampuran stater ke dalam susu yang telah di pasteurisasi.

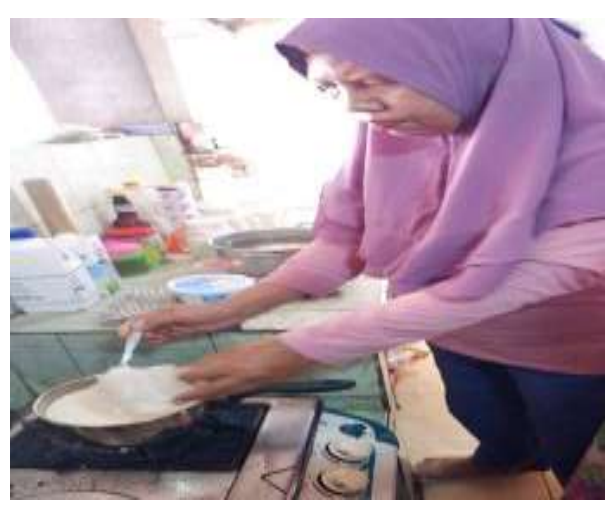

Gambar 2. Pendampingan di rumah mitra

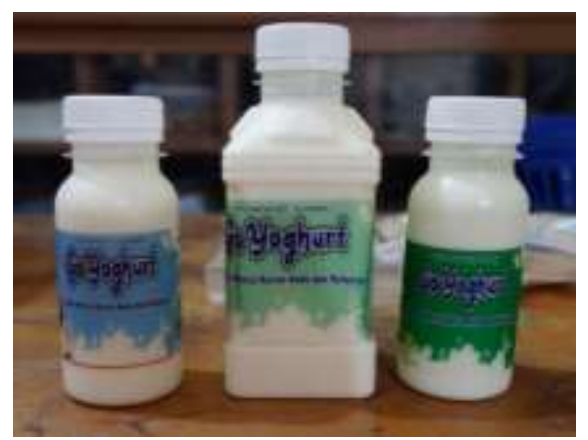

Gambar 3. Produk yoghurt berbahan baku susu sapi

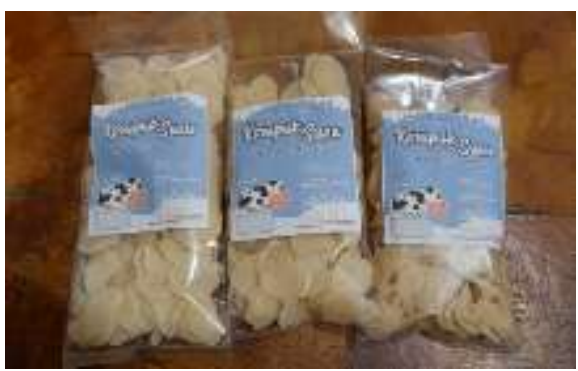

Gambar 4. Produk kerupuk susu berbahan baku susu sapi 
Penyuluhan dari kegiatan PKM ini tidak hanya memberikan pelatihan pembuatan yoghurt, melainkan juga memberikan penyuluhan mengenai perencanaan bisnis, pengelolaan keuangan dan pemasaran produk. Tim pengabdian memberikan pelatiahan mengenai pembuatan laporan keuangan dan penentukan harga pokok penjualan dan harga pokok produksi, hasil dari pelatihan ini yaitu mitra saat ini dapat mengelompokan biaya-biaya yang masuk ke dalam harga pokok penjualan dan harga pokok produksi sehingga mitra dapat lebih mudah menetapkan harga jual dari produk olahan berbahan baku susu sapi serta mitra dapat menyusun laporan keuangan sederhana sehingga dapat membantu mitra dapat melakukan pengadministrasian keuangan secara rapi. Penyuluhan terakhir yang diberikan mengenai strategi pemasaran. Dalam penyuluhan ini, diberikan materi mengenai bagaimana melakukan pemasaran yang mudah dan tidak memerlukan banyak biaya. Tim pengabdian memberikan pelatihan pemasaran produk dengan memanfaatkan teknologi. Pemanfaatan teknologi untuk membantu pemasaran produk baru yaitu melalui online, dimana mitra telah membuat media promosi melalui google my business, Instagram, facebook untuk memasarkan produk olahan susu. Mitra diajarkan bagaimana cara memasarkan teknologi dengan memanfaatkan teknologi, mulai dari pembuatan akun, pendaftaran ke google my business, share peta lokasi mitra sehingga konsumen bisa lebih muda menemukan tempat mitra. Selain memasarkan secara online, mitra juga memanfaatkan Bumdesmart untuk memasarkan produk olahan susu sapi. Hasil yang diperoleh dari pelatihan ini, mitra telah memiliki akun bisnis untuk mempermudah pemasaran produk olahan susu sapi.
Setelah mitra telah menerima semua materi pelatihan yang telah diberikan oleh tim pengabdian meliputi pengolahan produk susu, pencatatan dan penentuan harga pokok penjualan dan harga pokok produksi dan pemasaran, selanjutnya mitra dapat menjalankan bisnisnya secara mandiri. Tim juga melakukan pendampingan kepada mitra, untuk membantu mitra dalam memberikan solusi terkait dengan permasalahan yang dihadapi selama dalam menjalankan bisnisnya. Setelah dilakukan pendampingan dalam beberapa bulan, kendala yang ditemui oleh mitra yaitu terbatasnya plastik kemasan yoghurt (botol kemasan), mitra masih mengalami kesulitan untuk proses pengemasan, karena ketersediaan botol plastik ukuran kecil di wilayah Desa Seketi Kecamatan Balongbendo Kabupaten Sidoarjo masih sedikit, sehingga untuk kemasan botol plastik masih diperoleh dari Surabaya sehingga membuat proses pengemasan menjadi semakin lama.

Diakhir pelaksanaan kegiatan, tim PKM memberikan sebuah mesin pasteurisasi untuk membantu mitra dalam menjalankan kegiatan wirausahanya, yang nantinya dapat digunakan mitra untuk membantu proses produksi pembuatan yoghurt, selain itu mitra juga menerima kemasan yoghurt dan label untuk produk yoghurt, susu beranek rasa dan kerupuk susu. Adapun merk (brand) dari produk yoghurt yaitu "Go Yoghurt", go yoghurt ini memiliki arti untuk mengajak mayarakat untuk hidup sehat melalui konsumsi yoghurt yang diproduksi oleh Desa Seketi Kecamatan Balongbendo Kabupaten Sidoarjo. Dengan label produk yang telah disedikan oleh tim, maka mitra dapat langsung menjual produk olahan susu sapi ke masyarakat karena telah memiliki label produk. 


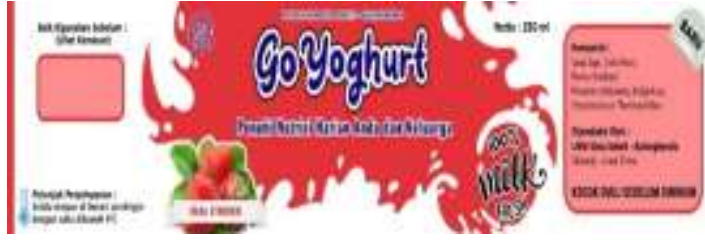

Gambar 5. Label produk

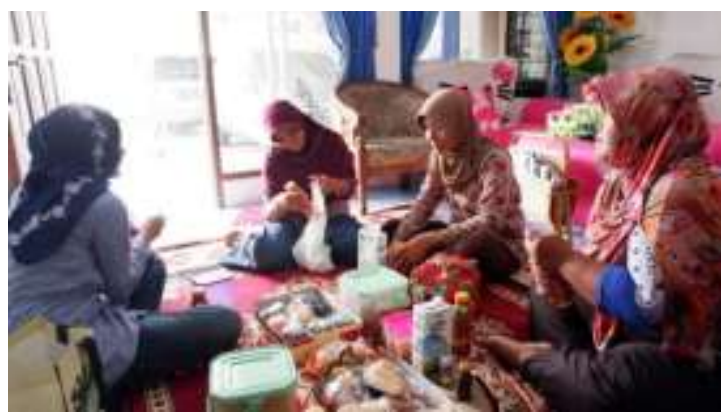

Gambar 6. Diskusi dengan mitra terkait kendala yang dihadapi

\section{PENUTUP}

\section{Simpulan}

Peternak sapi dan masyarakat desa Desa Seketi Kecamatan Balong-bendo Kabupaten Sidoarjo dapat meningkatkan perekonomian melalui produk olahan yang yang dihasilkan dari susu sapi. Mitra telah memiliki media promosi secara online sehingga dapat membantu mitra dalam memasarkan setiap produk yang dihasilkan. Selain itu mitra telah mampu menyusun pelaporan pencatatan keuangan.

\section{Saran}

Mitra dapat melanjutkan usaha produk olahan susu sapi dengan melakukan kaderisasi sehingga menjadi produk unggulan Desa Seketi Kecamatan Balongbendo Kabupaten Sidoarjo.

\section{Ucapan Terima Kasih}

Kami sebagai tim pengabdian mengucapkan terima kasih kepada Kementrian Riset, Teknologi dan Pendidikan Tinggi Republik Indonesia (Kemenristek Dikti) atas pendanaan untuk Program Kemitraan Masyarakat (PKM) tahun anggaran 2018.

\section{DAFTAR PUSTAKA}

Abu bakar dan M. Syawaludin. 2000. Perbandingan persentase susu kedelai dan susu sapi terhadap karakteristik yoghurt. Prosiding Seminar Nasional Peternakan dan Veteriner. Pusat Penelitian dan Pengembangan Peternakan. Bogor 18-19 Oktober 1999:443-450.

Dinas Peternakan Provinsi Jawa Timur. 2016. Data Produksi Ternak Kabupaten Sidoarjo.

Kotler, Philip dan Keller, Kevin Lane. 2012. Marketing Management $14^{\text {th }}$ Edition. New Jersey. Pearson-Prentice Hall.

Rahman, Syamsul dan Awwaliddin Rauf. 2013. IPTEKS Bagi Masyarakat (IBM) kelompok Usaha Dangke di Kabupaten Enkerang. Majalah Aplikasi Ipteks Ngayah. Vol.4 No.

Resnawati, Hetty. 2013. Kualitas Susu Pada Berbagai Pengolahan dan Penyimpanan. Semikola Nasional Prospek Industri Sapi Perah Menuju Perdagangan Bebas 2020. 
Republik Indonesia. 2014. Peraturan Presiden Republik Indonesia Nomor 98 Tahun 2014 tentang Perizinan Untuk Usaha Mikro dan Kecil. Lembaran Negara Republik Indonesia Tahun 2014 Nomor 222. Sekretariat Kabinet RI. Jakarta.

Suharyadi, dkk. 2011. Kewirausahaan Membangun Usaha Sukses Sejak Usia Muda. Jakarta : Salemba Empat. 